\title{
Colostomy Site
}

National Cancer Institute

\section{Source}

National Cancer Institute. Colostomy Site. NCI Thesaurus. Code C122640.

A surgically created external opening into the colon. 